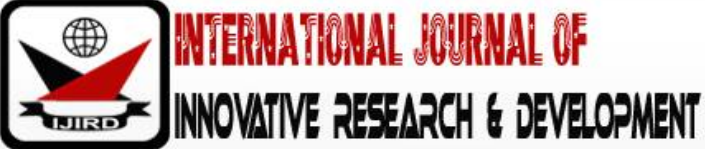

ISSN 2278 - 0211 (Online)

\section{Empirical Study of the Relationship or Otherwise of Corporate Governance on Organizational Performance: A Case of Cement Company of Northern Nigeria Plc (2009-2013) Sokoto, Nigeria}

\author{
Esuola Musibau Azeez \\ MS.C Student, Department of Business administration, University of Illorin, Nigeria \\ Jamilu Aliyu \\ Civil Servant, Department of Administration, Office of the Head of Service, \\ Niger State Government, Nigeria
}

\begin{abstract}
:
Businesses' success, whether micro, small, medium or large-scale depend on how best the resources are utilized by principal actors nay top management. Thus the coordination of principles, plans, strategies and actions to achieve organization effectiveness and efficiency that will allay conflicts of interests between Principal (Shareholders)) and Agents (Board of Directors/ Top management) and between Principal (Shareholders) and Principal (Shareholders) in such a way that leads to increased organization's performance variables namely: Shareholders' maximization, Profitability and Sales growth is fundamental. Therefore, it is important to strike a balance of the benefits of organization's performance amongst company's top management, shareholders and other stakeholders.

This research thus attempts to explore the significant relationship or otherwise of corporate governance mechanism: Board Size, Board Structure and CEO status on organization's performance. The organization's performance variables used in this study include only: Shareholders' wealth maximization (Return on Equity), Profit (Return on Investment) and sales growth.

This Study employs multiple regression models in models via statistical packages for social sciences (SPSS 17.0) in analyzing the relationship between corporate governance and organizational performance variables. Analysis for variance (ANOVA) at $5 \%$ significance level is used to test for the overall significance of the parameters in the study. The secondary sources of data gathering are the major tools used for the purpose of this study. This study covers the annual consolidated reports on sales growth, profitability and shareholders wealth maximization for each relevant year activities of Cement Company of Northern Nigeria. The study covers a period of five (5) years activities of the company, from 20092013.

The results show that there is a negative relationship between the Corporate Governance Mechanisms and Organization's performance indicators tested in this study. The board size, board structure and CEO status show p-value of 0.910, 0.923 and 0.410 respectively, which indicate that null hypothesis should be accepted because each of these levels of significance or $\mathrm{p}$-value are greater than $\alpha=5 \%=0.05$ level of significance in the critical table. The test for the overall significance equally reveals the same result as follows: $\mathrm{F}^{*}=\frac{M S R}{M S E}=0.653$ (Equivalentto 0.696 SignificantValue). The coefficient of determination $\mathrm{R}^{2}=0.662(66 \%)$ indicates that approximately $66 \%$ variation in the Corporate Governance Mechanisms is explained by the variation in shareholders wealth maximization. This means that about 34 percent variation in Corporate Governance Mechanisms is explained by other factors not captured in this study. Moreover, the study equally indicates the following: $\mathrm{F}^{*}=\frac{M S R}{M S E}=0.593$ (Equivalent to 0.715 Significant Value). Thus, the findings underscore the view of Hermalin et al (1991), John and Senbet (1998) whose hypotheses revealed that, there was no any relationship between board composition and organization performance.
\end{abstract}

Keywords: Organization's performance, shareholders' maximization, profitability, sales growth, shareholder, stakeholder, return on equity, return on investment, variable, Analysis of Variance (ANOVA)

\section{Introduction}

\subsection{Background to the Study}

Over the years, businesses have failed. This failure has been partly attributed to poor corporate governance practice. The recurring conflicts of interest between Principal (shareholders)----Agency (board of directors) and other stakeholders in managing often large corporations have become a threat to the success of many large corporations. This 
divergence of views between shareholders and board of directors may border on dividend policy, composition of board of directors, etc.

But there are also conflicts of interest amongst the shareholders which also pose somewhat serious danger on the overall performance of the company. These discrepancies of views and non-harmonious relations between Principal (shareholders) and Agent (board of directors) have been the thrust of Agency Theory as opined by (Coleman, 2007) and (Bamberg and Klaus 1987).

In Nigeria, Large corporations have shut down because of deviation to corporate governance principles. These companies have been mired with financial misappropriation, disregard to the interest of shareholders and other stakeholders, dishonesty and non-transparency.

The issue of corporate governance is a topic which is rapidly growing and fast gaining recognition globally to the point of being referred to as the science of organization (Dalton, 2008).

\subsection{Objectives of the Study}

- To determine whether or not corporate governance mechanisms have any relationship with shareholders' wealth maximisation.

- To examine whether or not there is any significant relationship between board size and organisation sales growth.

- To know whether or not good corporate governance is positively related to profitability

\subsection{Statement of Hypotheses}

The researchers postulate the following hypothetical statements as tentative answers, in order to test the validity and objectivity of the study. The hypotheses include:

- $\mathrm{H}_{0}$ : There is no any relationship between corporate governance mechanisms and shareholders' wealth maximisation.

- $\mathrm{H}_{0}$ : There is no any significant relationship between board size and organisation sales growth.

- $\mathrm{H}_{\mathrm{o}}$ : That good corporate governance mechanism does not increase profitability in organisation.

\subsection{Limitations to the Study}

- Non-availability of Sufficient Data: Poor access to and collection of data due to extreme data gaps and paucity. This compelled the researcher to limit the coverage of the study to only data available as at the time of carrying out this study.

- Skepticism of some respondents especially middle level managers from releasing important document to the researcher because of their fear and anticipation of the information being used against the company by their competitors. This thus limited the number of respondents involved in the study despite the researcher`s efforts and approaches to them explaining the significance of the study to them and other stakeholders.

\subsection{Methodology/ Research Design}

This is an empirical research designed to study the relationship between corporate governance mechanisms and organizational performance using the Cement Company of Northern Nigeria plc as a case study. The relevant mechanisms (board size, board structure and CEO status) and performance indicators (shareholders wealth, sales growth and profitability) are analyzed using the company`s annual consolidated reports for the period of five (5) years (2009-2013). The researcher utilizes multiple regression models in analyzing the relationship between the independent and dependent variables.

\section{Conceptual Clarifications}

\subsection{Concept of Corporate Governance}

Corporate Governance simply means application of procedures, principles, strategies, plans in a concise manner to manage organization's resources in an effective, efficient and transparent manner that will lead to increased performance of an organization whilst ensuring harmonious coordination of interests between shareholders, stakeholders and top management.

The broader perspective views corporate governance metaphorically as the heart of both a market economy and a democratic society (Oyejide and Soyibo, 2001). It is however from the view point of its narrow meaning that this study is based. Wilson (2006) defines corporate governance 'as the manner in which corporations are directed, controlled and held to account with special concern for effective leadership of the corporations to ensure that they deliver on their promise as the wealth creating organ of the society in a sustainable manner'. Oyejide and Soyibo (2001) jointly contend that, 'corporate governance is the relationship of the enterprise to shareholders or in the wider sense, the relationship of the enterprise to society as a whole'.

Jayashree (2006) as cited in Lai and Bello (2012) see corporate governance 'as concerned with the establishment of a system where directors are entrusted with responsibilities and duties in relation to the direction of corporation affairs.

Corporate governance is a system of making directors accountable to shareholders for effective management of the companies in the best interest of the company and the shareholders along with concern for ethics and values.

Organizations in this contemporary era have become major actors in the political economy of many countries. Under the current neo-liberal economic philosophy, they are regarded as the engine of sustainable growth and development. In order to ensure that these corporations not only survive but operate in the best interest of all stakeholders including the 
government, experts all over the world have unanimously agreed that good corporate governance is the only model and mechanism for organisations survival and effective performance.

Against this backdrop, these researchers attempt to examine whether or not there is any relationship between corporate governance mechanisms and organisations performance variables with a view to expanding the frontiers of knowledge. Though, outcomes of various studies carried out in the past had indicated different submissions, but whatever the outcome at the end of this study, would either uphold the existing ones or fill the vacuum created by lack of comprehensiveness of most of the initial studies.

\subsection{Theoretical Perspectives of Corporate Governance}

\subsubsection{Agency Theory}

Agency theory otherwise known as shareholder's model suggests that the organization can be viewed as a nexus of contracts between resource holders. An agency relationship arises wherever one or more individuals called principals, hire one or more other individuals called agents, to perform some service and then delegate decision-making authority to agents (Bamberg and Klaus 1987).

\subsubsection{Stakeholders Theory}

Freeman (1984) as cited in Lai and Bello (2012) offers a traditional definition of a stakeholder thus, "any group or individual who can affect or is affected by the achievement of the organization `s objectives".

\subsubsection{Stewardship Theory}

This theory states that a manager's primary objective is to maximize the performance of the corporation. This is because he is satisfied when the organization is attaining success (Davis et al, 1997) as cited in Muhammad (2012). As an alternative to agency theory, stewardship theory position on CEO status is duality, board size should be small, although no stipulation for optimal board size as well as encouraging active participation of Non-Executive Directors (NED) in decision making (Coleman, 2007).

\subsubsection{Resources Dependence Theory}

This theory seems to suggest that trust is low and the availability of relevant information it has at its disposal should be one of its strength for competitive reasons (Daily et al, 2003).

\subsection{Principles of Corporate Governance}

According to (David, 2011, Lai and Bello, 2012), the principles include:

\subsubsection{Accountability}

Accountability is concerned with an organization recognising that its actions affect the external environment, and therefore assuming responsibility for the effects of its action.

\subsubsection{Efficiency and Effectiveness}

Efficiency of course implies the transaction cost minimization whereas effectiveness must be interpreted in the context of achievement of the desired purpose. Thus, for effectiveness it is necessary that the process and institutions produce results that meet the needs of the organization while making the best use of resources at their disposal. Naturally this also means sustainable use of natural resources and the protection of the environment.

\subsubsection{Transparency}

Transparency, as a principle, necessitates that information is freely available and directly accessible to those who will be affected by such decisions and their enforcement. Transparency is of particular importance to external users of such information as these users lack the background details and knowledge available to internal users of such information.

\subsubsection{Integrity and Ethical Behaviour}

This is quite central to the practice of good corporate governance. It involves ethical and responsible decisions making which is necessary in managing risk and avoiding lawsuits. Corporate organizations should evolve a clear-cut code of conduct to guide the conduct of their directors and executives. This enhances their sense of duty and consciousness of the interest of all stakeholders.

\subsubsection{Right and Equitable Treatment of Shareholders}

This principle implies that there are certain fundamental rights of the shareholders which organizations must respect and strictly uphold. Shareholders should equally be allowed to exercise their rights without fear or favour. Organizations are duty bound to give clear interpretation of these rights for better understanding by the shareholders as well as ensuring shareholders ' participation in the affairs of the corporation through general meetings. 


\subsubsection{Responsiveness}

This is a corollary of the participation principle and transparency principle. Responsiveness implies that the governance regulations enable the institutions and process of governance to be able to serve all stakeholders within a reasonable time frame.

\subsection{Corporate Governance Models}

The emergence of many theoretical perspectives of corporate governance (CG) makes it clear that an objective of the organization differs along generally the agency theory and stakeholders' theory because the two theories primary concern is either protecting the interest of shareholders alone or non-shareholders in addition to the shareholders. This division led to two models of corporate governance, the Anglo-Saxon (shareholders) Model and Franco German (stakeholders). The organization's objective is to advance the interest of shareholders in the Anglo-Saxon Model while in Franco German model advancing the interest of other groups beyond the narrow category of shareholders such as suppliers, employees, creditors and communities is the corporate objective.

\subsubsection{Anglo Saxon Model of Corporate Governance}

This is also known as Anglo-American, shareholder, market based and outsider model. Countries practicing this model are called Anglo-Saxon countries; dominated in United State (US), United Kingdom, Canada and Australia (Mercy and O' Hara, 2003) The Anglo-Saxon model is characterized by highly developed market where managers are monitored by means of market based rewards and penalties, requiring adequate financial disclosure and protection of shareholders (Baron, 2008). The companies listed in the Anglo-Saxon model are usually many which made it possible for shareholders to spread their investment over more companies. Thus, the Anglo-Saxon model is characterized by low concentration of shareholders (Gup, 2008).

\subsubsection{Franco German Model}

The model is also known as insiders, continental, European and stakeholders' model. Countries practicing this model are called Franco-German or continental countries like Italy, German, France and Netherland are some of the countries (Hara et al, 2003). Under this model companies are, therefore, run for the benefit of other groups other than shareholders especially public, they are also concerned with survival, long term growth and stability. The interest of the society and the state are of great importance, creditors, employees, trade union and professional associations play an important role in corporate life (Gup, 2008).

This study is of the view that corporation governance should take a stakeholder's approach because issues in manufacturing industry like Cement Company of Northern Nigeria affect not only the shareholders but also their employees, suppliers, government and even the entire economy. Therefore, this study lends support to Franco German model of corporate governance mainly because the model's primary emphasis is on governing corporation to benefit other groups beyond the narrow group of shareholders.

\subsection{Corporate Governance Mechanisms and Control}

Corporate governance mechanisms and controls are designed to reduce the tendencies that arise from moral hazard and adverse selection. For instance, to monitor directors or manager's behavior, an independent third party or non-executive directors must attest to the accuracy of information provided by the management to investors. An ideal control system should regulate both motivation and ability.

In the same vein, Okeahalam and Akinboade (2003) have jointly emphasised that, discipline in modern corporations is induced by both internal and external factors. They further explain that, internally, effective governance systems are reflected in a set of relationships amongst the key players in a corporation. These would be reflected in the company`s code of conduct and auditing regulations. Internal arrangements, according to them, differ based on the ownership structure of the company. For a public-owned company with dispersed ownership, the manner of selection of board members is important.

\subsubsection{Internal Corporate Governance Mechanisms}

Internal corporate governance mechanisms and controls monitor activities and then take corrective actions to accomplish organizational goals. These include the following:

\subsubsection{The Role of the Board of Directors}

A director of a company is a custodian or trustee of the company`s resources and properties and is duly appointed to direct and manage the business of the company. The board of directors, with its legal authority to hire, fire, and compensate management, safeguards invested capital. Regular board meetings allow potential problems to be identified, discussed and avoided. While non-executive directors are thought to be more independent, they may not always result in more effective corporate governance and may not increase performance. Most regulatory framework requires that a company`s board of directors prepare financial statements reflecting a true and fair view of the operations of the company during the financial year. 


\subsubsection{Size of the Board of Directors}

The size of boards is believed to impact on the performance of the corporation. In this regard, Okeahalam and Akinboade (2003) argue that the market penalizes large boards i.e. those with membership between 4 and 10, beyond which no systematic relationship appears to exist.

\subsubsection{External Corporate Governance Mechanisms}

External corporate governance mechanisms and controls encompass the controls external stakeholders exercise over the organisation. These include laws, rules and institutions that provide a competitive playing field and discipline the behaviour of insiders, whether managers or shareholders

\section{Review of Empirical Studies}

Many business experts and researchers have carried out various empirical studies to examine the relationship between corporate governance and organization performance. Some of these studies found positive relationship between certain corporate governance variables and organization performance variables, while others found no relationship between the two sets of variables. This simply means that the results of the studies are inconclusive. According to Kyereboah et al (2006) as cited in Musa (2012), the main features of corporate governance adopted in various studies include board size, board composition, CEO duality and ownership structure. This section discusses the documented evidence of the relationships between organization performance and corporate governance mechanism that are adopted for the purpose of this study.

\subsection{Board Size and Organization Performance}

Kyereboah et al (2006) have argued that larger boards are better for corporate performance because they have range of expertise to help make better decisions and are difficult for powerful CEO to dominate. Nevertheless, Sandal et al (2005) and Lipton and Lorsch (1992) contend that large boards are less effective and are easier for a CEO to control. This is because when a board gets too big, it becomes difficult to coordinate and process problems. Sandal et al (2005), using the data from 93 Nigeria quoted firms, concur with Jensen (2001) and Lipton and Lorsch (1992) by asserting that organisation performance is positively related with small, as opposed to large boards.

\subsection{Board Composition and Organisation Performance}

There have been diverse opinions as to whether the board should be composed of more executive directors or more outside directors who have no tie with firm management (non-executive directors). Coleman and Biekpe (2006) report a positive relationship between board independent and organization value. They assert that outside directors may act as "professional referees" to ensure that competition among insiders results to actions consistent with shareholder value maximization. Conversely, Fama (1980) as cited in Kyereboah-Coleman (2007) favors more inside directors on the board because they are more familiar with the corporation activities and they act as monitors to top management, especially if they perceive the opportunity to advance into positions held by incompetent executives. Kyereboah-Coleman (2007) tends to support the existence of negative relationship between organization performance and board independence.

Young (2003) studied the correlation between governance and performance by addressing governance issues relating to Board of Directors and takeover defenses. His justification for governance variables chosen is because such governance mechanisms have received much attention from researchers and are considered important by institutional investors. He reviewed other people`s studies on takeover defense and board independence. Similarly, he highlighted some of the possible reasons for the differences in the outcome of various past studies on corporate governance and performance. His studies concluded that director`s independence has no positive impact on organization`s performance, by concluding that there is no link between governance and performance.

However, Hermalin et al (1991), John and Senbet (1998) deviate totally from the above findings with their findings revealed that, there is no any relationship between board composition and organization performance.

\subsection{Chief Executive Officer Status}

A widely debated corporate governance issue is whether the two most important positions in a company; the Chairman of the Board and the CEO-should be held by two different individuals (a dual leadership structure) or one person may be assigned both portfolios (a unitary leadership structure). Many studies addressed the CEO duality performance relationship; with inconsistent results (Brian K. Boyd 1994). There is only weak evidence that duality status affects long-term performance, after controlling the other factors that might impact the performance (Baliga et al, 1995). Berg et al (1978) and Brickley et al (1997) concluded that there is a chance of agency cost when CEO performs dual role. Therefore, the separation of the two positions enhances shareholder value. Fama et al (1983) also argued that concentration of decision management and decision control in one individual reduces a board's effectiveness in monitoring top management. For example, when a CEO doubles as board chairman, this results in conflict of interests and increases agency costs. The separation of CEO and chairman affects firms' performance because the agency problems are higher when the same person holds both positions.

Yermack (1996) shows that firms are more valuable when the CEO and board Chair positions are separate; by analyzing a sample of 452 U.S. public firms between (1984 and 1991).

Core, et al. (1999) finds that CEO compensation is lower when the CEO and board chair positions are separate. Brown and Caylor (2004) conclude that firms are more valuable when the CEO and board chair positions are separate. 
In conclusion, the findings of various studies reviewed above indicated that the outcomes on the exact relationship that exists between corporation performance and set of corporate governance mechanisms adopted vary.

\section{Observations/ Discussions}

This study makes use of multiple regression models via statistical packages for social sciences (SPSS 17.0) in analysing the variables involving the relationship between corporate governance and organisational performance.

\subsection{Multiple Linear Regression Model}

The aim in multiple regressions is to examine the nature of the relationship between a given dependent variable and two or more independent variables. In multiple linear regression, as in simple regression, the model describing the relationship between the dependent variable $\mathrm{Y}$ and a set of $\mathrm{K}$ independent variables, as expressed below: $\mathrm{X}_{1}, \mathrm{X}_{2},-$ - - $\mathrm{X}_{\mathrm{k}}$. The Multiple Linear Regression model can be expressed as:

$$
y=\beta_{0}+\beta_{1} X_{1}+\beta_{1} X_{1}+\beta_{2} X_{2}+\varepsilon
$$

Where the dependent variable $y$ is referred to as the response and the other parameters are defined as:

$\beta_{0}$-int ercept term

\section{$\left\{\beta_{1}, \ldots . \beta_{k}\right\}$ partial regression slopes}

\section{$\left\{X_{1}, \ldots . X_{k}\right\}$ predictor (independent) variables}

\section{-random residual assumed distributed as $N\left(0, \sigma^{2}\right)$}

$\operatorname{cov}()=0$ independent (independent residuals)

Note: The $X_{t}$ are assumed to be known and measured without error, it is the responses (observations), $y$, that are assumed to be variable.

The Five-year Annual consolidated reports from Cement Company of Northern Nigeria which form the empirical data used in this study are presented and analyzed as follows:

\begin{tabular}{|c|c|c|c|c|c|}
\hline $\begin{array}{l}\text { Year } \\
\text { Variables }\end{array}$ & 2009 & 2010 & 2011 & 2012 & 2013 \\
\hline Board Size & 12 & 11 & 15 & 15 & 14 \\
\hline Board Structure & $6 / 12$ & $8 / 11$ & $11 / 15$ & $10 / 15$ & $10 / 14$ \\
\hline CEO Status & 3 & 2 & 4 & 1 & 2 \\
\hline
\end{tabular}

Table 1: Corporate Governance Mechanisms

Source: Cement Company of Northern Nigeria 2009-2013

\begin{tabular}{|c|c|c|c|c|c|}
\hline Year & $\mathbf{2 0 0 9}$ & $\mathbf{2 0 1 0}$ & $\mathbf{2 0 1 1}$ & $\mathbf{2 0 1 2}$ & $\mathbf{2 0 1 3}$ \\
\hline Variables & 17.63 & 14.58 & 21.66 & 6.87 & 1.15 \\
\hline $\begin{array}{c}\text { Shareholders Wealth } \\
\text { Maximization (ROE) }\end{array}$ & 15.09 & 21.75 & 20.41 & 5.85 & 1.37 \\
\hline Sales Growth \% & 1.48 & 2.06 & 2.29 & 0.92 & 0.15 \\
\hline Profitability (ROI)\% &
\end{tabular}

Table 2: Firm's Performance Variables

Source: Cement Company of Northern Nigeria 2009-2013

4.2. Test of Hypothesis

\subsubsection{Hypothesis One}

- $\mathrm{H}_{0}$ : There is no any relationship between corporate governance mechanisms and shareholders' wealth maximisation.

- $\mathrm{H}_{1}$ : There is a relationship between corporate governance mechanisms and shareholders' wealth maximisation. 


\begin{tabular}{|c|c|c|c|c|c|c|}
\hline \multicolumn{2}{|c|}{ Model } & \multicolumn{2}{c|}{$\begin{array}{c}\text { Unstandardized } \\
\text { Coefficients }\end{array}$} & $\begin{array}{c}\text { Standardized } \\
\text { Coefficients }\end{array}$ & \multirow{2}{*}{ T } & \\
\cline { 3 - 7 } \multicolumn{2}{|c|}{} & B & Std. Error & Beta & & \\
\hline \multirow{3}{*}{1} & (Constant) & 12.565 & 39.409 & & .319 & .804 \\
\cline { 2 - 7 } & board size & -.670 & 4.720 & -.146 & -.142 & .910 \\
\cline { 2 - 7 } & $\begin{array}{c}\text { board } \\
\text { structure }\end{array}$ & -.523 & 4.286 & -.126 & -.122 & .923 \\
\cline { 2 - 7 } & CEO status & 5.644 & 4.242 & .774 & 1.331 & .410 \\
\hline
\end{tabular}

Table 3: Co-Efficients ${ }^{\mathrm{a}}$

a. Dependent Variable: Shareholders Wealth Maximization

The estimate of the regression equation from the above computation can be fitted as follow:

Shareholders wealth maximization $=12.565+(-0.670)$ board size $+(-0.523)$ board structure +5.644 (CEO status).

\subsubsection{Interpretation}

The Y-intercept $\left(\beta_{0}\right)$ or 12.565 is the estimated value of the shareholders wealth maximization when the board size, board structure and chief executive officer (CEO) status are zero.

The slope $\left(\beta_{1}=-0.670\right)$ means that on the average, shareholders wealth maximization decreases by 0.670 unit for every one unit increase in board size when board structure and CEO status are held constant.

The slope $\left(\beta_{2}=-0.523\right)$ means that on the average, shareholders wealth maximization decreases by 0.523 unit for every one unit increase in board structure when board size and CEO status remained constant.

The slope $\left(\beta_{3}=5.644\right)$ means that on the average of shareholders wealth maximization increase by 5.644 for every one unit increase in CEO status when the board size and board structure remained constant.

\subsubsection{Test for the Overall Significance of the Parameters Using Analysis of Variance (ANOVA)}

\subsubsection{Hypothesis Testing}

- $\mathrm{H}_{0}$ : Ther+e is no any relationship between corporate governance mechanisms and shareholders' wealth maximization.

Level of significance: $\alpha=0.05$

\begin{tabular}{|c|c|c|c|c|c|c|}
\hline \multicolumn{2}{|c|}{ ANOVA $^{\mathbf{b}}$} \\
\hline \multicolumn{2}{|c|}{ Model } & $\begin{array}{c}\text { Sum of } \\
\text { Squares }\end{array}$ & Df & Mean Square & F & Sig. \\
\hline \multirow{2}{*}{1} & Regression & 182.839 & 3 & 60.946 & .653 & $.696^{\mathrm{a}}$ \\
\cline { 2 - 8 } & Residual & 93.402 & 1 & 93.402 & & \\
\cline { 2 - 8 } & Total & 276.241 & 4 & & & \\
\hline
\end{tabular}

Table 4: Test Statistics

a. Predictors: (Constant), CEO Status, Board Structure, Board Size

B. Dependent Variable: Shareholder Wealth Max.

a. $\mathrm{F}^{*}=\frac{\text { MSR }}{M S E}=0.653$ (Equivalent to 0.696 significance value)

- Decision Rule

Ho.

Reject null hypothesis (Ho), if p-value or significant value is less than the level of significance, otherwise accept

- Conclusion

Since $\mathrm{F}^{*}=0.653$ (P-value $\left.=0.696\right)$ is greater than level of significance $(0.05)$, therefore we accept null hypothesis Ho and conclude that There is no any relationship between corporate governance mechanisms and shareholders wealth maximization.

\subsubsection{Test for Coefficient of Regression Using Student T-Distribution Hypothesis Testing for Constant.}

- Ho: Constant does not play any important role in the model. $\left(\beta_{0}=0\right)$

Level of significance: $\alpha=0.05$

\subsubsection{Test Statistics}

From the above table:

$\mathrm{T}^{*}=\frac{\beta 0}{S_{-E}(\beta 0)}=0.319(E q u$ valent to 0.804 significance value $)$

- Decision Rule

Reject null hypothesis Ho if p-value or significance value is less than level of significant. Otherwise accept null hypothesis Ho.

- Conclusion

Since T*=0.319 (0.804 p-value) is greater than level of significance therefore we accept null hypothesis and conclude that constant (12.565) does not play any important Role in the model. 
Hypothesis testing for slope $\left(\beta_{1}\right)$

Ho: There is no Relationship between shareholders wealth maximization and board size $\left(\beta_{1}=0\right)$

Level of significance: $\alpha=0.05$

\subsubsection{Test Statistics}

$\mathrm{T}^{*}=\frac{\beta 1}{S \cdot E(\beta 1)}=-0.142(E$ quivalent to 0.910 significarce value)

- Decision Rule

Reject null hypothesis (Ho), if p-value or significant value is less than a level of significance otherwise accepts Ho.

- Conclusion

Since T* $=-0.142$ (P-value $=0.910$ ) is greater than level of significance $(0.05)$, therefore we accept null hypothesis Ho and conclude that there is no relationship between shareholders wealth maximization and board size.

Hypothesis testing for slope $\left(\beta_{2}\right)$

Ho: There is no Relationship between shareholders wealth maximization and board structure $\left(\beta_{2}=0\right)$

Level of significance: $\alpha=0.05$

\subsubsection{Test Statistics}

$\mathrm{T}^{*}=\frac{\beta 2}{S . E\left(\beta_{2}\right)}=-0.122$ (Equivalent to 0.923 significance value)

- Decision Rule

Reject null hypothesis (Ho), if p-value or significant value is less than a level of significance otherwise accepts Ho.

- Conclusion

Since $\mathrm{T}^{*}=-0.122$ (P-value $=0.923$ ) is greater than level of significance $(0.05)$, therefore we accept null hypothesis Ho and conclude that there is no relationship between shareholders wealth maximization and board structure.

\subsubsection{Hypothesis Testing For Slope ( $\left.\mathrm{B}_{3}\right)$}

- Ho: There is no Relationship between shareholders wealth maximization and CEO Status $\left(\beta_{3}=0\right)$

Level of significance: $\alpha=0.05$

\subsubsection{Test Statistics:}

\section{$\mathrm{T}^{*}=\frac{B 3}{S . E(\beta a)}=1.331$ (Equivalent to 0.410 significance value)}

- Decision Rule

Reject null hypothesis (Ho), if p-value or significant value is less than a level of significance otherwise accepts Ho.

- Conclusion

Since $\mathrm{T}^{*}=1.331$ (P-value $=0.410$ ) is greater than level of significance $(0.05)$, therefore we accept null hypothesis Ho and conclude that there is no relationship between shareholders wealth maximization and CEO Status.

\begin{tabular}{|c|c|c|c|c|}
\hline \multicolumn{5}{|c|}{ Model Summary } \\
\hline Model & $\mathrm{R}$ & R Square & $\begin{array}{c}\text { Adjusted R } \\
\text { Square }\end{array}$ & $\begin{array}{c}\text { Std. Error of } \\
\text { the Estimate }\end{array}$ \\
\hline 1 & $.814^{\mathrm{a}}$ & .662 & -.352 & 9.66447 \\
\hline
\end{tabular}

Table 5: Measure of Correlation Coefficient

a. Predictors: (Constant), CEO Status, Board Structure, Board Size

In the table above, we observe that the correlation coefficient $r=0.814$ shows that there is strong correlation between Corporate Governance Mechanisms and Shareholders wealth maximization and coefficient of determination $\mathrm{R}^{2}=$ 0.662 (66\%) variation in Corporate Governance Mechanisms and Shareholders wealth maximization.

\subsection{Hypothesis Two}

- $\mathrm{H}_{0}$ : There is no any significant relationship between board size and organisation sales growth.

\begin{tabular}{|c|c|c|c|c|c|c|}
\hline \multicolumn{2}{|c|}{ Model } & \multicolumn{2}{c|}{$\begin{array}{c}\text { Unstandardized } \\
\text { Coefficients }\end{array}$} & $\begin{array}{c}\text { Standardized } \\
\text { Coefficients }\end{array}$ & \multirow{2}{*}{ T } & \multirow{2}{*}{ Sig. } \\
\cline { 3 - 5 } \multicolumn{2}{|c|}{} & B & Std. Error & Beta & & \\
\hline \multirow{2}{*}{1} & (Constant) & 39.251 & 43.899 & & .894 & .536 \\
\cline { 2 - 7 } & board size & -4.100 & 5.258 & -.830 & -.780 & .578 \\
\cline { 2 - 7 } & board structure & 1.888 & 4.774 & .421 & .396 & .760 \\
\cline { 2 - 7 } & CEO status & 4.825 & 4.725 & .613 & 1.021 & .493 \\
\hline
\end{tabular}

Table 6: Co-efficients ${ }^{\mathrm{a}}$

a. Dependent Variable: sales growth

The estimate of the regression equation from the above computation can be fitted as follow: Sales growth $=39.251+(-4.100)$ board size +1.888 (board structure) +4.825 (CEO status). 


\subsubsection{Interpretation}

The Y-intercept $\left(\beta_{0}\right)$ or 39.251 is the estimated value of the sales growth when the board size, board structure and chief executive officer (CEO) status are zero.

The slope $\left(\beta_{1}=-4.100\right)$ means that on the average, sales growth decreases by 4.100 unit for every one unit increase in board size when board structure and CEO status are held constant.

The slope $\left(\beta_{2}=1.888\right)$ means that on the average, shareholders wealth maximization increases by 1.888 unit for every one unit increase in board structure when board size and CEO status remained constant.

The slope $\left(\beta_{3}=4.825\right)$ means that on the average of sales growth increase by 4.825 for every one unit increase in CEO status when the board size and board structure remained constant.

\subsubsection{Test for the Overall Significance of the Parameters Using Analysis Of Variance (ANOVA)}

\subsubsection{Hypothesis testing}

- $\mathrm{H}_{0}$ : There is no any significant relationship between board size and organization sales growth.

\begin{tabular}{|c|c|c|c|c|c|c|}
\hline \multicolumn{2}{|c|}{ Model } & $\begin{array}{c}\text { Sum of } \\
\text { Squares }\end{array}$ & Df & $\begin{array}{c}\text { Mean } \\
\text { Square }\end{array}$ & F & Sig. \\
\hline \multirow{2}{*}{1} & Regression & 206.266 & 3 & 68.755 & .593 & $.715^{\mathrm{a}}$ \\
\cline { 2 - 7 } & Residual & 115.896 & 1 & 115.896 & & \\
\cline { 2 - 7 } & Total & 322.162 & 4 & & & \\
\hline
\end{tabular}

Table 7: ANOVA ${ }^{\mathrm{b}}$

Level of significance: $\alpha=0.05$

$\mathrm{F}^{*}=\frac{M S R}{M S E}=0.593$ (REquivalent to 0.715 Significant Value)

a. Predictors: (Constant), CEO status, board structure, board size

b. Dependent Variable: sales growth

- Decision Rule

Reject null hypothesis (Ho), if p-value or significant value is less than a level of significance otherwise accepts Ho.

- Conclusion

Since $\mathrm{F}^{*}=0.593$ (P-value $=0.715$ ) is greater than level of significance $(0.05)$, therefore we accept null hypothesis Ho and conclude that There is no any relationship between Corporate Governance Mechanisms and Sales growth.

\subsubsection{Test for Coefficient of Regression Using Student t-distribution Hypothesis Testing for Constant}

- Ho: Constant does not play any important role in the model. $\left(\beta_{0}=0\right)$

Level of significance: $\alpha=0.05$

\subsubsection{Test Statistics}

From the above table:

$\mathrm{T}^{*}=\frac{\beta 0}{S . E(\beta 0)}=0.894$ (Equivalentto 0.536 SignificanceValue)

- Decision Rule

Reject null hypothesis Ho if p-value or significance value is less than level of significant. Otherwise accept null hypothesis Ho.

- Conclusion

Since $T^{*}=0.894$ ( $0.536 \mathrm{p}$-value) is greater than level of significance therefore we accept null hypothesis and conclude that constant (39.251) does not play any important Role in the model.

\subsubsection{Hypothesis Testing for Slope ( $\left.\mathrm{B}_{1}\right)$}

- Ho: There is no Relationship between board size and sales growth $\left(\beta_{1}=0\right)$

Level of significance: $\alpha=0.05$

\subsubsection{Test Statistics}

$$
\mathrm{T}^{*}=\frac{\beta 1}{S . E(\beta 1)}=-0.780 \text { (Equivalentto } 0.578 \text { SignificanceValue) }
$$

- Decision Rule

Reject null hypothesis (Ho), if p-value or significant value is less than a level of significance otherwise accepts Ho.

- Conclusion

Since $T^{*}=-0.780$ (P-value $=0.578$ ) is greater than level of significance (0.05), therefore we accept null hypothesis Ho and conclude that there is no relationship between shareholders wealth maximization and board size.

\subsubsection{Hypothesis testing for Slope $\left(\beta_{2}\right)$}

- Ho: There is no Relationship between sales growth and board structure $\left(\beta_{2}=0\right)$

Level of significance: $\alpha=0.05$ 


\subsubsection{Test Statistics}

$$
\mathrm{T}^{*}=\frac{\beta 2}{S . E(\beta 2)}=0.396 \text { (Equivalentto } 0.760 \text { SignificanceValue) }
$$

- Decision Rule

Reject null hypothesis (Ho), if p-value or significant value is less than a level of significance otherwise accepts Ho.

- Conclusion

Since $\mathrm{T}^{*}=0.396$ (P-value $=0.760$ ) is greater than level of significance $(0.05)$, therefore we accept null hypothesis Ho and conclude that there is no relationship between sales and board structure.

\subsubsection{Hypothesis Testing for Slope ( $\beta 3$ )}

- Ho: There is no Relationship between Sales Growth and CEO Status $(\beta 3=0)$

Level of significance: $\alpha=0.05$

\subsubsection{Test Statistics}

$\mathrm{T}^{*}=\frac{\beta 3}{S . E(\beta 3)}=1.021$ (Equivalentto 0.493 SignificanceValue)

- Decision Rule

Reject null hypothesis (Ho), if p-value or significant value is less than a level of significance otherwise accepts Ho.

- Conclusion

Since $T^{*}=1.021$ (P-value=0.493) is greater than level of significance (0.05), therefore we accept null hypothesis Ho and conclude that there is no relationship between Sales Growth and CEO Status.

\begin{tabular}{|c|c|c|c|c|}
\hline \multicolumn{5}{|c|}{ Model Summary } \\
\hline Model & $\mathrm{R}$ & R Square & $\begin{array}{c}\text { Adjusted R } \\
\text { Square }\end{array}$ & $\begin{array}{c}\text { Std. Error of the } \\
\text { Estimate }\end{array}$ \\
\hline 1 & $.800^{\mathrm{a}}$ & .640 & -.439 & 10.76549 \\
\hline
\end{tabular}

Table 8: Measure of Correlation Coefficient

a. Predictors: (Constant), CEO status, board structure, board size

In the table above, we observe that the correlation coefficient $r=0.800$ shows that there is strong correlation between Corporate Governance Mechanisms and Sales Growth and coefficient of determination $R^{2}=0.640(64 \%)$ variation in Corporate Governance Mechanisms and Sales growth.

\subsection{Hypothesis Three}

- $\mathrm{H}_{0}$ : That good corporate governance mechanism does not increase profitability in organization.

\begin{tabular}{|c|c|c|c|c|c|c|}
\hline \multirow{2}{*}{ Model } & \multicolumn{2}{|c|}{$\begin{array}{c}\text { Unstandardized } \\
\text { Coefficients }\end{array}$} & $\begin{array}{c}\text { Standardized } \\
\text { Coefficients }\end{array}$ & \multirow{2}{*}{ t ig. } & \\
\cline { 3 - 5 } \multicolumn{2}{|c|}{} & B & Std. Error & Beta & & \\
\hline \multirow{3}{*}{1} & (Constant) & 34.936 & 47.886 & & .730 & .599 \\
\cline { 2 - 7 } & board size & -6.784 & 5.735 & -1.216 & -1.183 & .447 \\
\cline { 2 - 7 } & board structure & 6.454 & 5.208 & 1.274 & 1.239 & .432 \\
\cline { 2 - 7 } & CEO status & 3.358 & 5.154 & .378 & .652 & .632 \\
\hline
\end{tabular}

Table 9: Coefficientsa

a. Dependent Variable: Profitability

The estimate of the regression equation from the above computation can be fitted as follows: Profitability $=$ $34.936+(-6.784$ ) board size +6.454 (board structure) +3.358 (CEO status).

\subsubsection{Interpretation}

The Y-intercept $\left(\beta_{0}\right)$ or 34.936 is the estimated value of the Profitability when the board size, board structure and chief executive officer (CEO) status are zero.

The slope $\left(\beta_{1}=-6.784\right)$ means that on the average, profitability decreases by 6.784 unit for every one unit increase in board size when board structure and CEO status are held constant.

The slope $\left(\beta_{2}=6.454\right)$ means that on the average, profitability increases by 6.454 unit for every one unit increase in board structure when board size and CEO status remained constant.

The slope $\left(\beta_{3}=3.358\right)$ means that on the average of profitability increase by 3.358 for every one unit increase in CEO status when the board size and board structure remained constant.

\subsubsection{Test for the Overall Significance of the Parameters Using Analysis of Variance (ANOVA)}

\subsubsection{Hypothesis Testing}

- $\mathrm{H}_{0}$ : That good corporate governance mechanism does not increase profitability in organisation. 


\begin{tabular}{|c|c|c|c|c|c|c|}
\hline \multicolumn{2}{|c|}{ Model } & $\begin{array}{c}\text { Sum of } \\
\text { Squares }\end{array}$ & Df & $\begin{array}{c}\text { Mean } \\
\text { Square }\end{array}$ & F & Sig. \\
\hline \multirow{3}{*}{1} & Regression & 272.670 & 3 & 90.890 & .659 & $.694^{\mathrm{a}}$ \\
\cline { 2 - 7 } & Residual & 137.903 & 1 & 137.903 & & \\
\cline { 2 - 7 } & Total & 410.572 & 4 & & & \\
\hline
\end{tabular}

Table 10: ANOVA $^{\mathrm{b}}$

a. Predictors: (Constant), CEO Status, Board Structure, Board Size

b. Dependent Variable: Profitability

Level of significance: $\alpha=0.05$

$\mathrm{F}^{*}=\frac{\mathrm{MSR}}{\mathrm{MSE}}=0.659$ (Equivalent to 0.694 Significant Value)

- Decision Rule

Reject null hypothesis (Ho), if p-value or significant value is less than a level of significance otherwise accepts Ho.

- Conclusion

Since $\mathrm{F}^{*}=0.659$ (P-value=0.694) is greater than level of significance (0.05), therefore we accept null hypothesis Ho and conclude that good corporate governance mechanism does not increase profitability in organization.

\subsubsection{Test for Coefficient of Regression Using Student T-Distribution Hypothesis Testing for Constant}

- Ho: Constant does not play any important role in the model. $\left(\beta_{0}=0\right)$

Level of significance: $\alpha=0.05$

Test Statistics: From the above table:

$\mathrm{T}^{*}=\frac{\beta 0}{S . E(\beta 0)}=0.730$ (Equivalentto 0.599 SignificanceValue)

- Decision Rule

Reject null hypothesis Ho if $\mathrm{p}$-value or significance value is less than level of significant. Otherwise accept null hypothesis Ho.

- Conclusion

Since $T^{*}=0.730$ ( $0.599 \mathrm{p}$-value) is greater than level of significance therefore we accept null hypothesis and conclude that constant (34.936) is not play an important Role in the model.

Hypothesis testing for slope $\left(\beta_{1}\right)$

Ho: There is no Relationship between board size and profitability $\left(\beta_{1}=0\right)$

Level of significance: $\alpha=0.05$

\subsubsection{Test Statistics}

$\mathrm{T}^{*}=\frac{\beta 1}{S . E(\beta 1)}=-1.183$ (Equivalentto 0.447 SignificanceValue)

- Decision Rule

Reject null hypothesis (Ho), if p-value or significant value is less than a level of significance otherwise accepts Ho.

- Conclusion

Since $\mathrm{T}^{*}=-1.183$ (P-value=0.447) is greater than level of significance (0.05), therefore we accept null hypothesis Ho and conclude that there is no relationship between profitability and board size.

Hypothesis testing for slope $\left(\beta_{2}\right)$

Ho: There is no Relationship between board structure and profitability $\left(\beta_{2}=0\right)$

Level of significance: $\alpha=0.05$

\subsubsection{Test Statistics}

$\mathrm{T}^{*}=\frac{\beta 2}{S . E(\beta 2)}=1.239$ (Equivalentto 0.432 SignificanceValue)

- Decision Rule

Reject null hypothesis (Ho), if p-value or significant value is less than a level of significance otherwise accepts Ho.

- Conclusion

Since $\mathrm{T}^{*}=1.239$ (P-value=0.432) is greater than level of significance $(0.05)$, therefore we accept null hypothesis Ho and conclude that there is no relationship between profitability and board structure.

Hypothesis testing for slope $(\beta 3)$

- Ho: There is no Relationship between Profitability and CEO Status $(\beta 3=0)$

Level of significance: $\alpha=0.05$

\subsubsection{Test Statistics}

$\mathrm{T}^{*}=\frac{\beta 3}{S . E(\beta 3)}=0.652$ (Equivalentto 0.632 SignificanceValue)

- Decision Rule

Reject null hypothesis (Ho), if p-value or significant value is less than a level of significance otherwise accepts Ho.

- Conclusion 
Since $T^{*}=0.652$ (P-value $=0.632$ ) is greater than level of significance $(0.05)$, therefore we accept null hypothesis Ho and conclude that there is no relationship between profitability and CEO Status.

\begin{tabular}{|c|c|c|c|c|}
\hline \multicolumn{5}{|c|}{ Model Summary } \\
\hline $\begin{array}{c}\text { Mode } \\
\mathrm{l}\end{array}$ & $\mathrm{R}$ & $\mathrm{R}$ Square & $\begin{array}{c}\text { Adjusted R } \\
\text { Square }\end{array}$ & $\begin{array}{c}\text { Std. Error of the } \\
\text { Estimate }\end{array}$ \\
\hline 1 & $.815^{\mathrm{a}}$ & .664 & -.344 & 11.74319 \\
\hline
\end{tabular}

Table 11: Measure of Correlation Coefficient

a. Predictors: (Constant), CEO Status, Board Structure, Board Size

In the table above, we observe that the correlation coefficient $r=0.815$ shows that there is strong correlation between Corporate Governance Mechanisms and Profitability and coefficient of determination $\mathrm{R}^{2}=0.664$ (66\%) variation in Corporate Governance Mechanisms and Profitability.

\section{Summary of Findings}

The results have shown that there is a negative relationship between the Corporate Governance Mechanisms and Organization's performance indicators tested in this study. In Table 1, the board size, board structure and CEO status respectively shown p-value of $0.910,0.923$ and 0.410 respectively, which indicated that null hypothesis should be accepted because each of these levels of significance or p-value are greater than $\alpha=5 \%=0.05$ level of significance in the critical table. The test for the overall significance in the Table 2 equally revealed the same result as follows: $\mathrm{F}^{*}=\frac{M S R}{M S E}=$ 0.653 (Equivalentto 0.696 SignificantValue). The coefficient of determination $\mathrm{R}^{2}=0.662(66 \%)$ in table 4.3.1c indicating that approximately $66 \%$ percent variation in the Corporate Governance Mechanisms is explained by the variation in shareholders wealth maximization. This means that about 34 percent variation in Corporate Governance Mechanisms is explained by other factors not captured in this study. Moreover, table $4.3 .2 \mathrm{~b}$ equally indicated the following: $\mathrm{F}^{*}=\frac{\mathrm{MSR}}{\mathrm{MSE}}=$ 0.593 (Equivalent to 0.715 Significant Value).It is obvious from this findings that all the three hypotheses tested using multiple regression models have shown negative relationship between Corporate Governance Mechanisms and Organizational Performance indicators. However, this finding underscores the view of Hermalin et al (1991), John and Senbet (1998) whose hypotheses revealed that, there was no any relationship between board composition and organization performance.

\section{Conclusion}

This study concludes that the board size, board structure and CEO status (either dual leadership role or unitary role) have no relationship with the organizational performance as can be inferred from the various statistical computations in the last chapter.

\section{Recommendations} researcher.

In light of the above findings and conclusion drawn, the following are the recommendations given by the

- That good corporate governance should be used as a tool to help stem the tide of unethical behavior among the internal board of directors, as it entails conformity with prudential guidelines.

- The directors at Cement Company of Northern Nigeria should improve on their disclosure of true and fair view of the operations of the company during the financial year as required by CAMA 2004 and in line with the corporate affairs commission's guideline.

- The office of the Chief Executive Officer and that of Chairman board of directors should be separated because by concentrating decision management and control in one individual, this reduces the board's effectiveness in monitoring top management.

- The board size / structure should not be too large so that maximum efficiency can be achieved in an organization.

- The company should develop effective internal and external controls mechanisms to check the excesses of management staff and other stakeholders of the corporation.

- All stakeholders' interests should be protected at all times, and encouraged to participate in the corporate governance process.

- There should be a system of independent sub-committees of the board, especially the finance and audit and remuneration committees of the company.

- The Cement Company of Northern Nigeria PLC should create an excellent relationship between the board, the management and other stakeholders. This can be achieved by regular consultations and that all stakeholders are carried along.

\section{References}

i. ACCA (2009) Corporate Governance: Sustainability Briefing Paper 4, Published by ACCA, United Kingdom.

ii. Adams, M. A. (2002). "The Convergence of International Corporate Systems - where is Australia heading? (Part 1), Keeping Good Companies Journal, 54(1), 14-21.

iii. Alexandru, P. and Lulia, P. (2012) "Failure of Corporate Governance-intention or Negligence". The ICFAI Journal of corporate Governance, vol. 5, pp. 1-26. 
iv. Bejamin, M. and Peter, W. (2011), "Corporate Governance Practice in Developing

v. Countries: The Case for Kenya". International Journal of Business Administration. Vol.2(1).

vi. Bernard, I. (2012) "Corporate Governance in Nigeria: What we Need to do" The Punch Nigeria1 7th May, 2013.

vii. Beth, Y. (2003) "Corporate Governance and Firm Performance: Is there a Relationship? Ivey Business Journal".

viii. Boston, I. and Grosu, V. (2010), "The Role of Internal Audit in Optimisation of Corporate Governance at the Groups of Companies", Journal of Applied Economics, vol. xvii, No. 2(543), pp.89 -110. Cutting, B. \& Kouzim, A. (2000) "The emerging patterns of power Corporate Governance back to the future in improving corporate decision making". Journal of Managerial Psychology, 15(5), 477507.http:/ / dx.doi.org/ 10.1108/ 02683940010337211.

ix. x. David, C. And Shahla, S. (2011) Corporate Governance and International Businesses. N Ventus Publishing Aps, United Kingdom.

x. IFAC (2009) "Evaluating and Improving Governance in Organisation". International Good Practice Guidance Publication. Pp. 1-25.

xi. Ifeanyi, et al (2011) "Corporate Governance and Bank Failure in Nigeria: Issues, Challenges and Opportunities". Research Journal of Finance and Accounting. Vol. 2, No.2, Pp. 1-19.

xii. Josiah, A. et al (2013), "An Empirical Test of Competing Corporate Governance Theories76NMHJYUon the Performance of Firms Listed at the Nairobi Securities Exchange". European Scientific Journal, May 2013 edition, vol.9, No. 13, pp. 1-31.

xiii. Laib, A. et al (2011) "Corporate Governance and Firm Performance "Global Journal of Management and Business Research".Vol. 11, No. 8, pp 1-11.

xiv. Lai, S. and Bello, S. (2012) "The Concept and Practice of Corporate Governance in Nigeria: The Need for Public Relations and Effective Corporate Commission".

xv. Journal of Communication. Vol. 3 (1), pp. 1-16. Lucian, A. And Michael, S. (2009) "The State of Corporate Governance Research".

xvi. Journal of National Bureau of Economic Research, Cambridge. Vol. 8, pp. 1-39.

xvii. Olusoji, et al (2012) Corporate Governance and National Culture are Siamese Twin: The Case of Cadbury (Nigeria) Plc". International Journal of Business and Social Science. Vol. 3, No. 15, pp.269-278.

xviii. Rajiv Ghandhi (2012) "Corporate Governance and Company Performance - A Study with reference to Manufacturing Firms in India". Journal of Finance. Vol. xv11, pp. 1-

xix. Yahya Bin Ali (2012) The Impact of the Global Economic Crises on the International Relations. (Unpublished Ph. D Thesis), Szent Istvan University. 